Bryn Mawr College

Scholarship, Research, and Creative Work at Bryn Mawr College

2010

\title{
Continuity and Change in the Eastern Aleutian Archaeological Sequence
}

Richard S. Davis

Bryn Mawr College, rdavis@brynmawr.edu

R.A. Knecht

Let us know how access to this document benefits you.

Follow this and additional works at: http://repository.brynmawr.edu/anth_pubs

Part of the Anthropology Commons

\section{Citation}

Davis, Richard S. and Richard A. Knecht. "Continuity and Change in the Eastern Aleutian Archaeological Sequence." Human Biology 82, no. 5-6 (2010): 507-524.

This paper is posted at Scholarship, Research, and Creative Work at Bryn Mawr College. http://repository.brynmawr.edu/anth_pubs/7

For more information, please contact repository@brynmawr.edu. 


\title{
Continuity and Change in the Eastern Aleutian Archaeological Sequence
}

\author{
RICHARD S. DAVIS ${ }^{1}$ AND RICHARD A. KNECHT ${ }^{2}$
}

\begin{abstract}
The eastern Aleutian prehistoric archaeological sequence is key for understanding population movements, cultural exchanges, and adaptations to environmental changes over a wide area of the north Pacific and Bering Sea during the Holocene. An important question is, Can the settlement history of the eastern Aleutians be understood as a single continuous tradition lasting some 9,000 years, or were there major population and cultural influxes along with periods of widespread population abandonment? We review the available archaeological evidence with reference to recent mtDNA and nucleic DNA studies of prehistoric and contemporary Arctic and Subarctic populations and conclude that the evidence points to an overall cultural continuity with notable incursions and excursions of people and cultural elements into and out of the eastern Aleutians.
\end{abstract}

The eastern Aleutian region begins on the Alaska Peninsula at Port Moller and extends about $750 \mathrm{~km}$ westward through the Fox Island group to the Islands of the Four Mountains (Figure 1). This stretch of territory begins as a narrowing landmass studded with numerous volcanic cones and edged by coastlines of the north Pacific and the Bering Sea. The Aleutian chain then arcs toward Asia along a string of islands between $58^{\circ}$ and $52^{\circ} \mathrm{N}$ latitude. The first known people to come to this area came about 9,000 years ago and were almost exclusively oriented toward coastal living and marine resources. It has mostly stayed that way ever since. When the Russians arrived in 1741, they named the inhabitants of the region Aleut, as they had for nearly everyone else living in the coastal and island regions from Kamchatka to Kodiak. Today people of the eastern Aleutians generally prefer the name Unangan to Aleut, and it is no small issue how far back in time that ethnic identity can be traced.

For more than a century archaeologists have excavated and surveyed in the eastern Aleutians. Notable early investigators include William H. Dall (1877),

\footnotetext{
${ }^{1}$ Department of Anthropology, Bryn Mawr College, 101 N. Merion Ave., Bryn Mawr, PA 19010.

${ }^{2}$ Department of Archaeology, School of Geosciences, University of Aberdeen, St. Mary's, Elphinstone Road, Aberdeen, AB24 3UF, Scotland, UK.
}

Human Biology, October-December 2010, v. 82, nos. 5-6, pp. 507-524.

Copyright (C) 2010 Wayne State University Press, Detroit, Michigan 48201-1309

KEY WORDS: EASTERN ALEUTIANS, PREHISTORIC ARCHAEOLOGY, EASTERN ALEUTIAN PREHISTORY, ARCTIC SMALL TOOL TRADITION, HOG ISLAND, AMAKNAK ISLAND, MARGARET BAY, UMNAK ISLAND, UNALASKA ISLAND. 
508 / DAVIS AND KNECHT

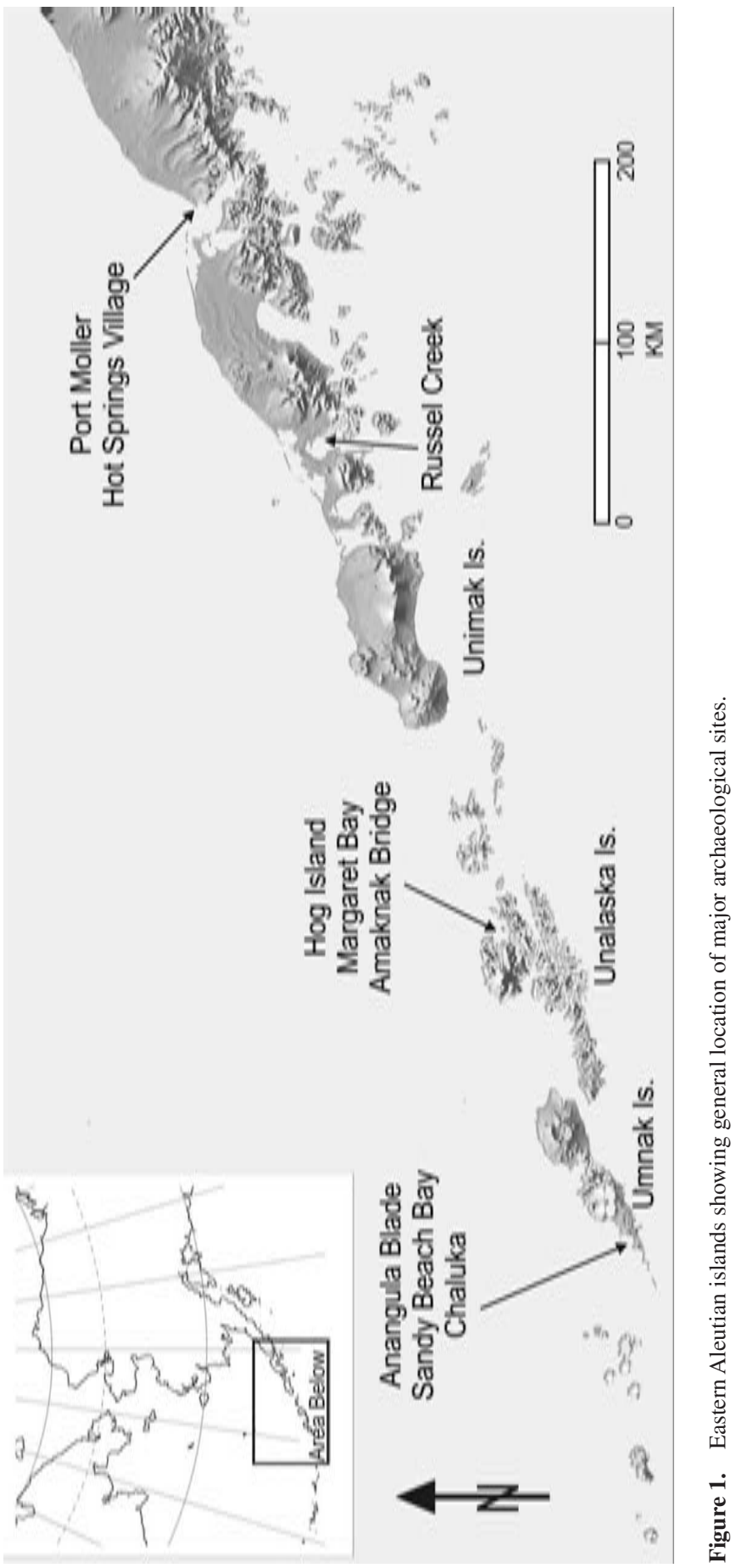


Waldemar Jochelson (1925), and Aleš Hrdlička (1945). A substantial amount of archaeological and skeletal material has been recovered, but there is a less ample collection of published site reports and synthetic works. McCartney (1984) and Dumond (2001a) have produced integrative works that have proved useful for archaeologists trying to conceptualize a framework for Aleutian cultural history. We have also outlined an archaeological sequence for the eastern Aleutians (Knecht and Davis 2001) and are following up here with additional observations.

For many years, the most widely accepted view of the Aleutian archaeological sequence was articulated by McCartney (1984). McCartney held that Aleutian prehistory is best divided into two successive but probably unrelated cultural traditions: Anangula and Aleutian. The Anangula was relatively short-lived and represented the initial occupancy of the archipelago about 9,000 years ago. Its chipped-stone core, blade, and microblade technology was unique in Alaskan maritime cultures, and its origins could most likely be traced to the "great Upper Paleolithic traditions" of Siberia (McCartney 1984: 124). According to McCartney, after an occupational hiatus of about 3,500 years, the Aleutian tradition began and continued with little apparent change in material culture until the time of contact with Europeans. This period is often referred to in the literature and in popular discourse as the midden period, and its thick shell midden sites have been the object of excavation since the days of Dall, Jochelson, and Hrdlička. McCartney (1984: 124) observed that "Alaska mainland Eskimo influences" are strongly evident in the Aleutian tradition. In addition, the Aleutians as a whole were considered a region of relative cultural homogeneity and environmental constancy. This static quality was melded with a picture of relative cultural isolation from developments elsewhere in Alaska.

Our understanding of the eastern Aleutian archaeological sequence has been informed by a series of excavations and surveys on Unalaska, Amaknak, and Hog islands. As a result, we have developed a picture of a much more dynamic environmental and cultural system that lasted throughout the Holocene. We have unearthed probative evidence for a much more continuous archaeological sequence. As detailed in this paper, we find that the Anangula tradition extends over several millennia, and we have divided it into two phases, Early and Late Anangula. Unlike the earlier view, we have clear indications for significant midto late Holocene climatic change, which affected shorelines, sea ice extent, and fauna. Moreover, there is good evidence of contact with peoples as far away as Kodiak beginning early in the sequence. Human populations, perhaps the ancestors of the modern Unangan, responded to the changing environmental conditions technologically, socially, and ideologically, and we can see reflections of these adaptations in the archaeological record.

\section{Field Research and Methods}

Archaeological Sequences. An archaeological sequence for a given region is meant to give a sense of the variations in artifact and feature assemblages 
as a measure of cultural continuity and change. In the traditional American archaeological-cultural-historical approach, sequences are composed of a number of phases that have been defined through the formal variation of artifacts and features from a number of sites or archaeological components (Willey and Phillips 1958). Further, the phases are generally chronologically controlled through a variety of relative and absolute dating techniques. The degree of artifact similarity in technology, style, and function between phases has a variety of causes, including internal culture change and cultural discontinuities brought about by the arrival of peoples from outside the region or through adaptations to environmental variations.

Archaeological sequences are clumpy in most instances, because they are derived from a limited number of well-excavated and reported sites that cumulatively span a considerable length of time. The total number of archaeological components that make up a regional sequence represents only a tiny fraction of the total material record actually produced by the various communities that lived in the area. Hence particular archaeological sites chosen as the defining bases for sequences need to be regarded with some caution because they may be overly influential in forming our image of the sequence as a whole.

Archaeological sequences, despite the just mentioned constraints, are the basis of regional archaeological inquiry. Their construction has heuristic value for the testing of ideas concerning the process of culture change and many other concerns of contemporary archaeology.

Establishing occupational continuity over several millennia is a difficult archaeological task. Conventionally, the most available means include stratigraphy, radiocarbon dating, and archaeological seriation. Stratigraphic sequences can help establish whether major and widespread disconformities in the archaeological record are present. Frequently depositional evidence of climatic or ecological change that created an unfavorable environment for settlement may be apparent. Radiocarbon dating can be used to correlate archaeological components from a number of locations.

Field Research. The eastern Aleutian archaeological sequence was derived from a series of substantial excavations that we carried out between 1996 and 2003. The excavation emphasis was on opening large horizontal exposures to discern complete features, such as habitation structures, storage pits, and middens, and to recover artifacts in primary depositional context. Hand tools were used exclusively for excavation, and artifacts and features were plotted with a total station, which gave excellent three-dimensional spatial control of the excavation. At several sites we used wet screening, which increased artifact recovery rates, especially of small chipped-stone and bone tools and faunal remains. Some general characteristics of the sites we excavated are given in Table 1.

Sites were selected for excavation in an attempt to span the entire sequence. Selection criteria included information from previous surveys and excavations, surface artifacts, degree of secondary disturbance, and logistical considerations. 
Table 1. Characteristics of Sites Excavated by the Authors and Used as the Basis for Formulating the Eastern Aleutian Archaeological Sequence

\begin{tabular}{lllccc} 
Site & Site Name & $\begin{array}{c}\text { Year of } \\
\text { Excavation }\end{array}$ & $\begin{array}{c}\text { Horizontal } \\
\text { Exposure }\left(m^{2}\right)\end{array}$ & $\begin{array}{c}\text { Approximate } \\
\text { Collection Size }\end{array}$ & $\begin{array}{c}\text { Chronology } \\
2 \sigma \text { Cal. BP }\end{array}$ \\
\hline UNL-55 & Tanaxtaxak & 2001 & 44 & 3,500 & $306-652$ \\
UNL-92 & Summer Bay & 1998 & 564 & 3,300 & $1705-2716$ \\
UNL-50 & Amaknak Bridge & 2000,2003 & 260 & 30,000 & $2492-3835$ \\
UNL-46 & Agnes Beach & 1999 & 3 & 300 & $3565-6180$ \\
UNL-48 & Margaret Bay & $1996-1997$ & 76 & 13,500 & $3212-6406$ \\
UNL-115 & Russian Spruce & $1997-1999$ & 28 & 624 & $8592-9477$ \\
UNL-318 & Uknodok & 2001 & 38 & 800 & $8661-9121$ \\
\hline
\end{tabular}

In addition to the sites we excavated, several key eastern Aleutian sites that we took into account in the compiling of our sequence are shown in Table 2.

Stratigraphy and Radiocarbon Chronology. In the eastern Aleutians large prehistoric sites are common; however, excavated and reported multicomponent sites (sites with superimposed occupational levels with distinct cultural characteristics) are rare (see Tables 1 and 2). The Margaret Bay site on Amaknak Island (Knecht et al. 2001) is a notable exception, as is the Chaluka Mound on Umnak Island (Turner et al. 1974). In addition, the Hot Springs Village site is a multicomponent occupation. When coupled with the Anangula phase localities, these sites provide important bases for the regional sequence.

Radiocarbon dating has been an integral part of our sequence analysis. All determinations from the Unalaska sites were made on wood charcoal and were calibrated in years before present (BP) using the CALIB 6.0.1 program (Stuiver and Reimer 1993) and the IntCal09 data set for northern hemisphere terrestrial samples (Reimer et al. 2009).

Table 2. Key Sites for Eastern Aleutian Archaeological Sequences by Location

\begin{tabular}{lll} 
Island & \multicolumn{1}{c}{ Site Name } & \multicolumn{1}{c}{ Reference } \\
\hline Umnak & Chaluka & Aigner (1978) \\
& Sandy Beach Bay Village & Aigner et al. (1976) \\
& Anangula Village & Laughlin (1975) \\
& Anangula blade & Laughlin (1975) \\
Unalaska & Reese Bay (UNL-63) & Veltre and McCartney (2001) \\
& Quarry (UNL-469) & Rogers et al. (2009) \\
Unimak/Lower Alaska Peninsula & Agayadan Village (UNL-067) & Hoffman (1999) \\
& Hot Springs Village & Okada et al. (1986) \\
& Russell Creek (XCB-022) & Maschner and Jordan (2001) \\
\hline
\end{tabular}




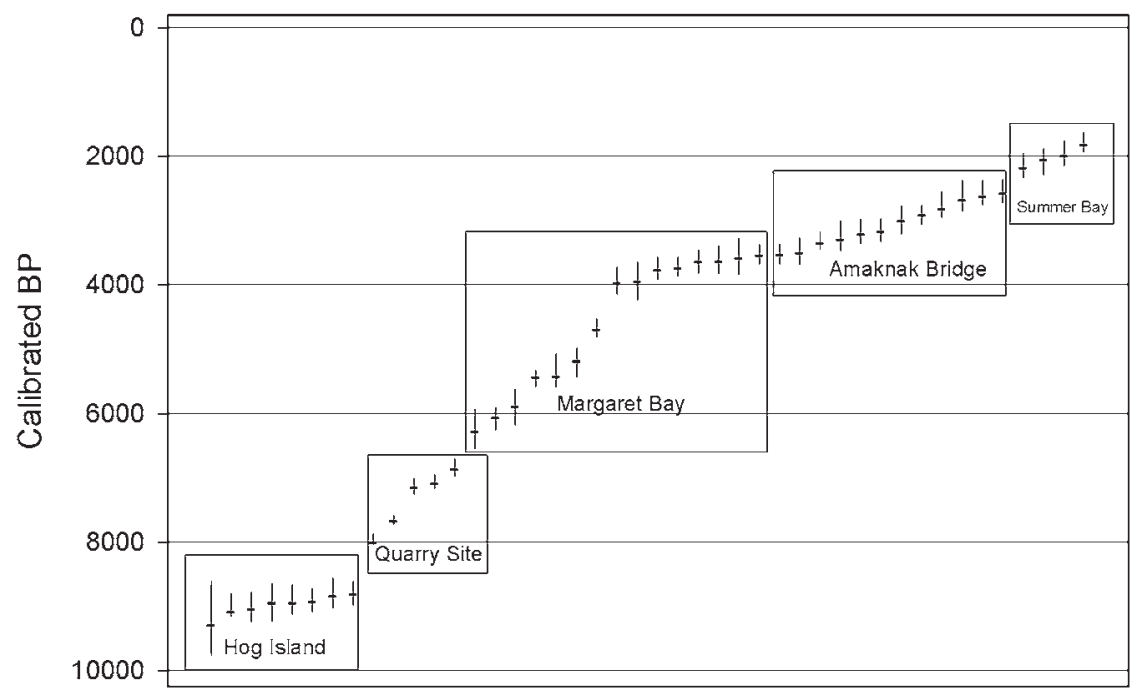

Figure 2. Unalaska radiocarbon dates (cal. BP). Symbols show $2 \sigma$ range and median probability.

Calibrated radiocarbon determinations from excavations at the Hot Springs Village site have shown a span of occupation from approximately $3950 \mathrm{BP}$ to 550 $\mathrm{BP}$, close to 3,500 years (Maschner 2004). At Margaret Bay the radiocarbon dates range from $6406 \mathrm{BP}$ to $3212 \mathrm{BP}$, more than 3,000 years (Knecht et al. 2001). At the Chaluka mound dates begin as early as $4550 \mathrm{BP}$-certainly by $3950 \mathrm{BP}$ - and a recent series of accelerator dates taken from skeletons near the top of the mound extend past 550 BP (Coltrain et al. 2006). Thus at Chaluka the time span represented is on the order of 3,500 years.

\section{Results}

Figure 2 is a plot of all the ${ }^{14} \mathrm{C}$ determinations from Unalaska. Until the dating of the Amaknak Quarry site (UNL-469 on Amaknak Island) there was a sizable gap in the ${ }^{14} \mathrm{C}$ sequence between $8950 \mathrm{cal}$. $\mathrm{BP}$ and $6250 \mathrm{cal}$. BP. The new ${ }^{14} \mathrm{C}$ dates reported by Rogers et al. (2009) from the quarry site on Amaknak Island span more than 1,000 years from $8040 \mathrm{cal}$. BP to $6740 \mathrm{cal}$. BP Another, briefer gap in the sequence appears between $4850 \mathrm{BP}$ and $3950 \mathrm{BP}$. Thus, based on available radiocarbon dates, there is a prima facie case for some occupational discontinuities, but overall for continuity. Radiocarbon dates from adjacent areas also show significant related gaps. On the Alaska Peninsula dates between 8450 BP and 5950 BP and from 4350 to 3950 BP are absent (Maschner 1999). Further east on the Aleutian chain beyond Umnak there is no evidence of Anangula-age materials, and there is scant evidence for any sites before 5950 BP (Hatfield 2006; O'Leary 2001). 
The archaeological phases we previously defined for the eastern Aleutians are summarized in Table 3 (Knecht and Davis 2001). As described in the following sections, these phases are cultural-historical constructs that have consistent chronological and stratigraphic definition. They are rubrics that reflect the general archaeological picture for Umnak and Unalaska and to some degree the lower Alaska Peninsula. The phasing has withstood some scrutiny by our colleagues (Dumond 2001b; Hatfield 2006), but it certainly may be subject to future refinement.

\section{Discussion}

The degree of continuity in an archaeological sequence is usually determined in two ways. First, radiocarbon dating is often combined with stratigraphic analysis to detect unconformities and chronological gaps. Second, the persistence of particular feature and artifact types, technologies, and styles is recognized as a marker of cultural continuity. The two approaches do not always yield the same results, as we discuss later. Continuity issues for the Early and Late Anangula phases and for the Margaret Bay phase are our primary focus.

Early Anangula Phase. The Anangula Blade site on Anangula Island is a single-component occupation in a layer $10-30 \mathrm{~cm}$ thick lying between welldefined volcanic ash layers. The site may well have been abandoned as a result of a volcanic eruption. A number of radiocarbon determinations have been made for the Anangula Blade site, and according to William Laughlin the dates "showed that the people had lived there for about 1,500 years, between 7,200 and 8,700 years ago" (Laughlin 1980: 65). Laughlin's interpretation of the radiocarbon dates has been challenged on a variety of grounds, and a much briefer interval of 500 years or less is a well-supported estimate (Aigner 1976; Black 1974; Dumond and Bland 1995; McCartney and Veltre 1996). Based on the relatively thin occupation layer and inconsistencies in the radiocarbon determination series, we also agree that the occupation was relatively brief and may be dated to approximately $9000 \mathrm{cal}$. BP.

On Hog Island in Unalaska Bay we excavated two localities (UNL-115, Russian Spruce site; and UNL-318, Uknodok site) that are similar in artifact types to the original Anangula Blade site (Dumond and Knecht 2001; Knecht and Davis 2001). Both sites were contemporaneous single-component occupations capped by an overlying pyroclastic flow deposit. The fast-moving gas and ash came from a caldera-forming eruption by nearby Mt. Makushin. The pyroclastic flow was immediately on top of the occupation; if any inhabitants were present, they would have been overcome by the conflagration. The eruption was dated by four determinations (Bean 1999: 108), which have a sum of probabilities at $2 \sigma$ of 9,462-8,603 cal. BP. The archaeological sites have seven radiocarbon determinations on wood carbon samples, and their sum of probabilities is 9,402-8,593 cal. BP, virtually identical to the tephra dating. The occupation layers at both Hog Island sites were thin (10-30 $\mathrm{cm}$ ) and extensive. As at the Anangula Blade site, there was no midden accumulation. Subsequent tephra falls over the millennia buried the site to a depth of $1.4 \mathrm{~m}$. 


\section{4 / DAVIS AND KNECHT}

Table 3. Sequence of Archaeological Phases for the Eastern Aleutians

\begin{tabular}{|c|c|c|c|}
\hline Phase & $\begin{array}{c}\text { Approximate } \\
\text { Chronology }(\text { Cal. BP })\end{array}$ & $\begin{array}{c}\text { Type Site } \\
\text { in Unalaska Bay }\end{array}$ & $\begin{array}{c}\text { Diagnostic Artifacts } \\
\text { and Features }\end{array}$ \\
\hline Late Aleutian & $1000-200$ & $\begin{array}{l}\text { Tanaxtaxak (UNL-55), } \\
\text { Eider Point (UNL-19), } \\
\text { Reese Bay (UNL-63), } \\
\text { Morris Cove (UNL- } \\
\text { 9), Bishop's House } \\
\text { (UNL-59) }\end{array}$ & $\begin{array}{l}\text { Abundant ground slate, } \\
\text { ulus, and limited } \\
\text { chipped-stone inven- } \\
\text { tory; multiple-room } \\
\text { houses and longhouses } \\
\text { and fortified refuge } \\
\text { rocks }\end{array}$ \\
\hline Amaknak & $3000-1000$ & $\begin{array}{l}\text { Summer Bay (UNL-92), } \\
\text { Cahn site D (UNL-18), } \\
\text { Amaknax (UNL-54) }\end{array}$ & $\begin{array}{l}\text { Appearance of stemmed, } \\
\text { notched lithics, elabo- } \\
\text { rate barbing on bone } \\
\text { hunting implements, } \\
\text { toggling harpoons, } \\
\text { asymmetric knives, } \\
\text { spall scrapers, and } \\
\text { umqan; rectangular } \\
\text { houses }\end{array}$ \\
\hline Margaret Bay & $4000-3000$ & $\begin{array}{l}\text { Amaknak Bridge (UNL- } \\
\text { 50); Margaret Bay } \\
\text { (UNL-48), levels } 2 \\
\text { and 3; Tanaxtaxak, } \\
\text { basal level; Agnes } \\
\text { Beach (UNL-46), } \\
\text { upper level }\end{array}$ & $\begin{array}{l}\text { Blades, ASTt-like tools, } \\
\text { stone bowls, plummets, } \\
\text { and angle and polished } \\
\text { burins; first appearance } \\
\text { of labrets, unilateral } \\
\text { barbs on harpoons, } \\
\text { bone socket pieces, } \\
\text { net sinkers, and exotic } \\
\text { lithics; stone-walled } \\
\text { houses }\end{array}$ \\
\hline Late Anangula & $7000-4000$ & $\begin{array}{l}\text { Margaret Bay, levels } 4 \\
\text { and 5; Agnes Beach, } \\
\text { lower level; Airport } \\
\text { site (UNL-105); } \\
\text { Powerhouse site } \\
\text { (UNL-114); Cahn site } \\
\text { K (UNL-47); Quarry } \\
\text { site (UNL-469) }\end{array}$ & $\begin{array}{l}\text { Abundant blades, } \\
\text { stemmed points, and } \\
\text { bilateral barbed har- } \\
\text { poons with line guards; } \\
\text { first bifacial tools; shal- } \\
\text { low semisubterranean } \\
\text { houses }\end{array}$ \\
\hline Early Anangula & $9000-7000$ & $\begin{array}{l}\text { Russian Spruce site } \\
\text { (UNL-115), Uknodok } \\
\text { (UNL-318) }\end{array}$ & $\begin{array}{l}\text { Abundant blades, unifa- } \\
\text { cial tools, transverse } \\
\text { burins, large end scrap- } \\
\text { ers, grooved cobble } \\
\text { sinkers, ocher grinders, } \\
\text { stone bowls, and oil } \\
\text { lamps; tentlike houses } \\
\text { on shallow depressions }\end{array}$ \\
\hline
\end{tabular}


All the Early Anangula sites have a limited variety of chipped-stone tool types. The most represented artifacts are blades, microblades, and transverse burins. Only a few scrapers are present, and there is absolutely no evidence of bifacial tools or bifacial retouching. Other artifacts from Hog Island include stone lamps, ocher grinders and pallets, hammer stones, net sinkers, grooved scoria abraders, and cobble choppers. The artifact inventory from the Anangula Blade site was similar in proportion and variety to Hog Island.

Excavations at Uknodok uncovered a shallow, ovoid depression with red ocher and scattered charcoal on its floor. Only $3 \mathrm{~m} \times 1.5 \mathrm{~m}$ in size with two post molds on the exterior, the structure must have been a tentlike shelter. Somewhat larger but ill-defined depressions were excavated at Anangula. These depressions also have red ocher stains, and some have small hearths with charcoal and subfloor storage pits (Aigner 1974, 1976).

Aigner interpreted the high density of lithic remains, the wide horizontal extent of the cultural layer, and the tight cluster of house depressions in the excavated areas at the Anangula Blade site to mean that there may have been a local population as large as 100 individuals and that the site was occupied on a permanent basis (Aigner 1974:15). A basically similar set of circumstances describes the Hog Island site, but we offer an alternative interpretation. The restricted tool inventory, the thin occupation layer, the ephemeral structures, and the horizontal extent of the site suggest to us that the site was occupied seasonally a number of times by a relatively small group who were engaged in some specialized extractive activities. The abundant burins and grooved scoria abraders suggest bone and/ or wood working, which in turn suggests production and/or maintenance of tools. Most likely sea mammal hunting was the focus of the economic activity. Given the abundance of snapped blades and microblades in the Anangula sites, it seems likely that the inhabitants may have used laterally slotted bone lance points, as was observed on early Ocean Bay sites on Kodiak (Hausler-Knecht 1993). In lieu of chipped-stone bifacial endpoints, these projectiles could have been tipped with ivory, antler, or bone points or harpoons.

We recognize, of course, that more Early Anangula sites are waiting to be found and that they may present a different picture of a settlement system. For now, however, we have evidence of relatively ephemeral settlements on two small islands on the Bering Sea side of two large volcanic islands. They may represent the initial pioneer movements of a maritime people into the Aleutians as the climate warmed early in the Holocene, or they may be seasonal sites associated with winter settlements that remain to be located.

After Early Anangula. Easily the most enigmatic part of the sequence follows the abandonment of the Early Anangula sites. On the basis of radiocarbon dating and stratigraphy alone, there are clearly gaps until the lowest cultural strata at the Margaret Bay site (see Figure 2). The recently reported quarry site on Amaknak Island (Rogers et al. 2009) provides significant new dating. Basically the short-lived Anangula sites ended at approximately $9000 \mathrm{cal}$. BP; the Quarry site, 
according to five carbon determinations, dates roughly between 8000 and 7000 cal. BP, and the lowest level at Margaret Bay began at approximately 6000 BP. The Quarry site has not been fully excavated, but it has a small sample of artifacts; important details of the stratigraphy and extent of the site are still unknown. It is difficult to judge whether the site represents a long-term occupation or a much briefer interval akin to the Hog Island sites. The Quarry site, therefore, does not fill the entire gap between the Early and Late Anangula phases, but it certainly provides solid evidence of human presence at a critical time in our sequence. Other potential sites may provide important information for this time period when they are excavated. As we reported previously (Knecht and Davis 2001: 273274), there are several surface sites with blades and occasional bifaces on Amaknak Island at elevations between $8 \mathrm{~m}$ and $20 \mathrm{~m}$ above sea level. Although undated by radiocarbon dating, the stratigraphic context of these sites is well above the distinctive 9,000-year-old pyroclastic tephra, suggesting that these sites may well fall into the interval between the Early Anangula and level 5 at Margaret Bay.

In contrast to the radiocarbon dating, the archaeological evidence from the artifacts and features provides the basis for a strong argument of continuity. More than 25 years ago McCartney concluded that the discontinuity between the Anangula and Aleutian traditions was well marked: "The general lack of core and blade evidence in the older midden sites such as Chaluka ... supports a model of cultural discontinuity" (McCartney 1984: 124). Our excavations at the Margaret Bay site on Amaknak Island led us to the opposite conclusion because the core, blade, and microblade tradition was definitely the basis for the chipped-stone technology at 6000 cal. BP and continued for two millennia more. It was richly abundant in levels 5 and 4 and continued through level 3 into level 2 (Knecht et al. 2001). Chronologically this shows that the core, blade, and microblade technology continued beyond 4000 cal. BP. Dumond held that the evidence from Margaret Bay "promotes a sufficient suspension of disbelief to allow one to conceive of continuity without painful reservation" (Dumond 2001b: 290). Much earlier, Aigner held that the Aleut pattern was established in Anangula times and that there was strong evidence for cultural continuity "in the morphology and inferred functions of major tool categories from Anangula and later sites" (Aigner and Del Bene 1982: 54). In summing up the archaeological sequence, Aigner et al. (1976: 87) concluded: "There is little question of Aleut continuity in the Southwest Umnak area over the last 8,500 radiocarbon years; what is of particular interest is the nature of the continuity and of variation over time." This conclusion was reached on the basis of the multicomponent stratigraphy at Chaluka and a sequence of radiocarbon determinations from a number of sites on Umnak Island. Laughlin pointed to possible sites on Umnak Island that would demonstrate continuity, namely, the Anangula Village site and Sandy Beach Bay (Aigner and Del Bene 1982; Laughlin 1975).

In more specific terms the case for continuity between Early Anangula and later eastern Aleutian archaeological phases is built on a series of artifact types. Microblades are frequent at the Anangula Blade site, Hog Island, and in levels 2-5 at Margaret Bay. In the Anangula phase sites on Hog Island, microblades are 
removed from a variety of small circular (but not wedge-shaped) cores. Macroblades are abundant in the Early Anangula phase and also in levels 5 and 4 at Margaret Bay. Transverse burins are the most frequent type of shaped chipped-stone artifact in the Anangula phase, and they are present, albeit at low frequency, in level 4 in Margaret Bay. Ground- and pecked-stone artifacts show great continuity throughout the entire archaeological sequence. Oil lamps, notched cobbles (net sinkers), and ocher grinders are found in all phases. If there was an occupational hiatus between the Early and Late Anangula phases, the material cultural elements nevertheless show striking continuity, suggesting the intervals were not of great duration. Table 4 indicates the major tool classes and their degree of continuity through the entire eastern Aleutian archaeological sequence.

The most frequently noted distinction between the Early and Late Anangula phases is that the Early Anangula has absolutely no evidence of bifacial chippedstone artifacts, whereas the Late Anangula has an abundance of bifacial projectile points in many forms. A single biface was recovered from the quarry site, which may indicate that bifacial technology appeared in the eastern Aleutians sometime between 7000 and $8000 \mathrm{cal}$. BP. It is difficult to judge the significance of bifacial chipped-stone points and knives. Early Anangula peoples must have enjoyed success in marine mammal hunting, although they had no stone points-bifacial or unifacial—of any kind. Ethnographically the Unangan commonly used ivoryand bone-tipped projectiles to take seals, sea lions, and walrus; only whales were hunted almost exclusively with stone-tipped harpoons (Liapunova 1996: 97-101; Veniaminov 1984: 284). Because chipped-stone bifacial points are known to be extremely effective hunting weapons, particularly against large mammals (Ellis 1997), their introduction in the Late Anangula phase may well mark more formidable hunting equipment and perhaps new hunting techniques.

Late Anangula Phase. The Late Anangula phase is best known from levels 4 and 5 of the Margaret Bay site on Amaknak Island. It is characterized by chippedstone bifaces, particularly stemmed and large lanceolate points, bilaterally barbed keystone-based bone harpoons with line guards, and composite fishhooks.

As has been well documented by Davis (2001), the fauna associated with the Late Anangula phase (especially level 4 at Margaret Bay) includes polar bear, walrus, and ringed seal. The presence of these animals clearly reflects sea ice and probably the beginning of the Neoglacial period. The cooling climate apparently brought sea ice seasonally to the northern shores of the eastern Aleutians and with it an expanded resource base. These newly arrived ice-obligate mammalian species were exploited through the Margaret Bay phase (Crockford and Frederick 2007; Knecht and Davis 2008).

Demographically, during the Late Anangula phase, evidence of increased population growth and expansion is present. Levels 4 and 5 at Margaret Bay appear to reflect much more permanent settlements than anything that came during the Early Anangula phase. During this time at Margaret Bay there was a deep midden with abundant fish and marine mammals and a much more elaborated tool 


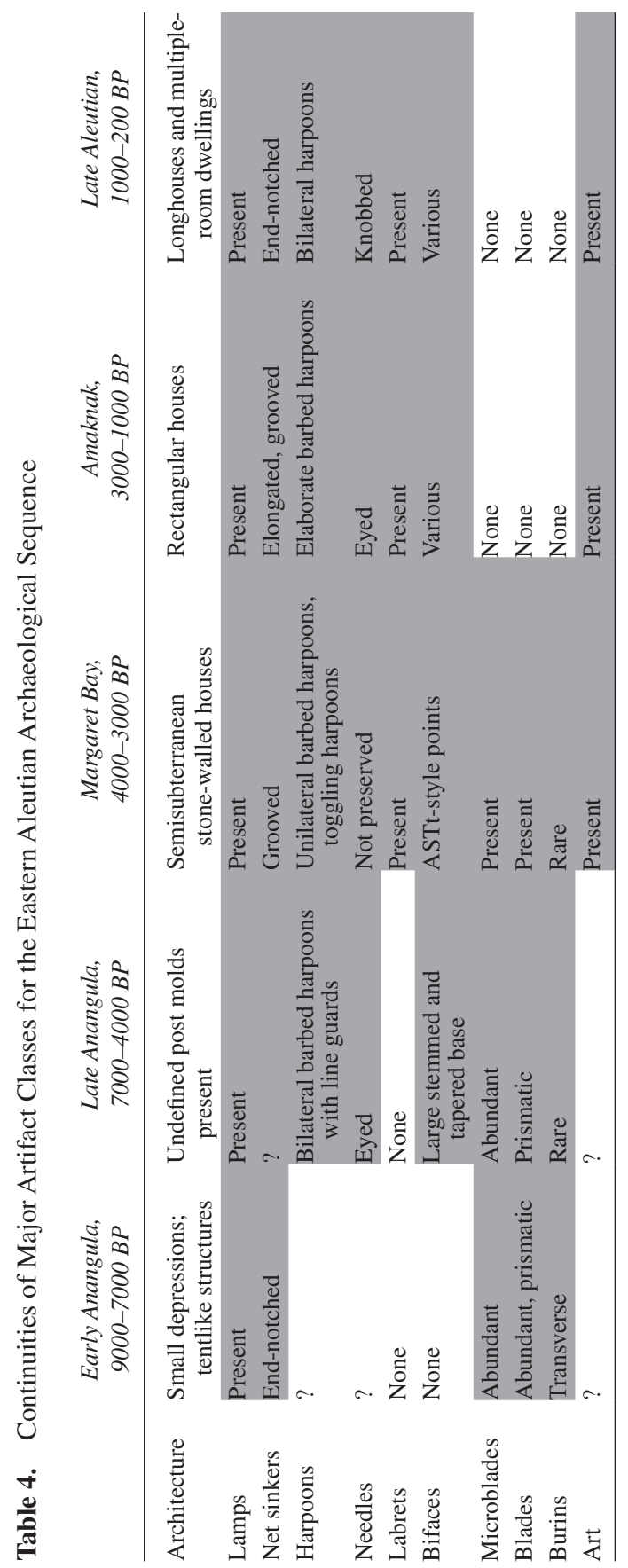


kit. Evidence of a more stable and actually growing population at that time comes from mtDNA analysis, reported by Zlojutro et al. (2006: 455). From mtDNA samples from contemporary populations in the Aleutians, distinct subclade clusters, identified by reduced median network analysis, suggest population expansion at an estimated age of $5400 \mathrm{BP}$. This dating for the appearance of the distinctive Aleut mtDNA subclades is close to the oldest archaeological levels at Margaret Bay. Thus the available demographic evidence favors a view of a well-established eastern Aleutian population that was beginning to grow and expand westward along the Aleutian chain, and eastward its influences have been recognized as far away as Kodiak.

Margaret Bay Phase. The Margaret Bay phase (4000-3000 BP) was defined in Unalaska Bay from a series of sites found on a fossil shoreline perched about $2 \mathrm{~m}$ above current mean sea level (Knecht and Davis 2004). The phase is best known from its namesake, the Margaret Bay site (UNL-48), and for its terminal and transitional aspects at the Amaknak Bridge site (UNL-50). Core and blade technology was present in the Margaret Bay phase but became rare later in time and is virtually absent by $3000 \mathrm{BP}$. Traces of contact with the Alaska Peninsula and Kodiak area are evident in the form of some ground slate points and jet ornaments.

The Margaret Bay phase tool kit is characterized by microblades, small end scrapers, beaked end scrapers, gravers, flake knives, bipoints, small bifacially chipped points, polished adzes, and polished burins or burinlike tools. These finely made tools are diagnostic of the Arctic Small Tool tradition (ASTt) (Davis and Knecht 2005; Knecht et al. 2001). We would not, however, characterize the entire assembly as ASTt because it is combined with a number of traits already long present in the eastern Aleutian sequence (Dumond 2005). The Russell Creek site on Unimak Island also has ASTt elements (Maschner and Jordan 2001).

The various ASTt elements combined with more indigenous artifacts suggest possible movement of ASTt-bearing peoples into the area. One indicator of the ASTt pulse on Unalaska was the sudden appearance of small projectile points with a mean weight of less than $1.7 \mathrm{~g}$, arguably used to tip arrows, which appear in the middle of the Margaret Bay phase. Two hundred eighty-two complete or broken small bifacial points were associated with other ASTt elements in level 2 in contrast to only three small points cataloged for the earlier level 3 (Davis and Knecht 2005: 59). This certainly indicates a discontinuity, in marked contrast to the generally gradual appearance of artifact types in the eastern Aleutian sequence (Davis and Knecht 2005). It also suggests that contact with ASTt peoples may have been brief but direct—and quite possibly violent.

Recent reports of Paleo-Eskimo DNA from Greenland (Gilbert et al. 2008; Rasmussen et al. 2010) provide a significant context for the ASTt character of the Margaret Bay phase. The genetic evidence suggests that the originators of the ASTt came from northeast Siberia sometime between 4,400 and 6,400 years ago and traveled east across the high Arctic all the way to Greenland and south along the western Alaskan margin to the Alaska Peninsula and ultimately the Aleutians. 
No close genetic connection with Inuit or Na-Dene populations was indicated. The Margaret Bay level 2, which reflects the ASTt influence or intrusion, is dated to between 3214 and 3681 cal. BP. Four to five centuries earlier, ASTt peoples had appeared at the base of the Alaska Peninsula (Dumond 2005). Thus, within a millennium of their arrival in North America, ASTt peoples had left clear traces of their presence in a wide arc from the Aleutians to Greenland.

Dwellings during the Margaret Bay phase were larger and more substantial than the preceding phases, measuring about $7 \mathrm{~m}$ in diameter and embedded into the earth as deep as $75 \mathrm{~cm}$, and the house pit was lined by a substantial and carefully constructed stone wall. The first course of the wall was typically a row of upright stone slabs, followed by courses of cobbles and sometimes one or two whale vertebrae. Hearths were deep and stone lined and were vented to the outside through a hole in the wall leading to a chimney. By the end of the Margaret Bay phase, large multiroomed rectangular houses were in use, and their traces have been discovered at the Amaknak Bridge site. Stone-lined V-shaped ditches in the floor converged at the hearth, possibly to aid in venting the fire and preventing downdrafts. The ditch and hearth format are strongly reminiscent of so-called midpassage or axial features in early Dorset and ASTt houses in the eastern Arctic (Davis and Knecht 2005; Maxwell 1985).

Continuity of occupation throughout this phase is suggested stratigraphically by evidence from Margaret Bay, where no volcanic tephra lenses separated any of the cultural levels that extended to a depth of nearly $4 \mathrm{~m}$ across the site. This suggests no settlement hiatus of more than a century or two at the site because tephra deposits from volcanic activity are frequent and widespread in this area. We cannot confirm the same observation for Chaluka and the Hot Springs Village site.

\section{Conclusions}

The picture we have developed for eastern Aleutian prehistory differs significantly from what was widely accepted less than two decades ago. The program of excavations we undertook in Unalaska opened a series of seven sites between 1996 and 2003. In total, block excavations opening extensive horizontal exposures removed more than $700 \mathrm{~m}^{3}$ of deposit. More than 40,000 artifacts were cataloged. The large-scale excavations provided a window allowing the recognition of structural features previously unknown in the Aleutians.

Chief among the discoveries was the confirmation of Early Anangula phase occupations on Hog Island, the existence of which had been guessed at by a previous survey (McCartney and Veltre 1996). These occupations are directly analogous to those known from the original finds by Laughlin at the Anangula Blade site. People at this time occupied the eastern Aleutians episodically and left no middens or substantial structural remains. Their chipped-stone tool industry is quite limited in tool variety, suggesting specialized hunting activity.

After the Early Anangula we find cultural continuity at the Margaret Bay site on Amaknak Island, where we followed up on earlier testing (Yarborough 
1988; Yesner and Mack 1995). Blades and microblades from the basal levels of Margaret Bay are frequent, and they reflect the same technology known from the Early Anangula phase. It remains somewhat unclear what the degree of occupational continuity was following the Early Anangula phase sites. The Quarry site provides important evidence for human presence in the post-Early Anangula phase. There are other localities, as yet unexcavated, in the Unalaska district that may shed more light on this interval. Nevertheless, a warming climate and loss of sea ice after $8100 \mathrm{cal}$. BP (Mason 2001) may have made portions of the eastern Aleutians periodically uninviting for marine hunter-gatherers.

The Margaret Bay phase has been a major focus of our research, and significant cultural changes occurred within it. At this time substantial stone-walled semisubterranean dwellings with subfloor storage are found on Umnak (lower Chaluka) and Amaknak (Margaret Bay and Amaknak Bridge). The abundant faunal remains from Margaret Bay level 4 and Amaknak Bridge, including ringed seal and bearded seal, indicate much cooler temperatures and the presence of sea ice in the spring and early summer. Cooler temperatures may have led to greater productivity of the marine ecosystem and to the abundance of fish and marine mammals. In level 2 at Margaret Bay there is a horizon of Arctic Small Tool tradition artifact types, and this gives testimony to the adaptive capabilities of this widespread archaeological culture, which appeared throughout the North American Arctic at this time.

In sum, we find an essential continuity in the prehistoric sequence in the eastern Aleutians that dates back to initial settlement some 9,000 years ago. The archaeological record demonstrates the continued use of basic lithic, bone, and ground-stone technologies throughout major portions of the entire sequence. Nevertheless the radiocarbon dating, stratigraphy, and ephemeral nature of the earliest sites strongly suggest that populations were thinly dispersed and at times possibly absent.

Current archaeological and genetic data appear to tell the same story. First, the inference of population expansion from genetic data at approximately 5400 BP is supported by the more permanent and widespread settlement during the Late Aleutian phase. Second, genetic similarities between contemporary inhabitants of the eastern Aleutians and northeast Siberia most likely stem from early ASTt population movements into the New World and is echoed by the suite of ASTt elements found in the Margaret Bay phase.

Received 7 June 2010; accepted for publication 29 June 2010.

\section{Literature Cited}

Aigner, J. S. 1974. Studies in the early prehistory of Nikolski Bay: 1937-1971. Anthropol. Pap. Univ. Alaska 16:9-25.

Aigner, J. S. 1976. Dating the early Holocene maritime village of Anangula. Anthropol. Pap. Univ. Alaska 18:51-62. 
Aigner, J. S. 1978. Activity zonation in a 4,000-year-old Aleut house, Chaluka village, Umnak Island, Alaska. Anthropol. Pap. Univ. Alaska 19:11-25.

Aigner, J. S., and T. Del Bene. 1982. Early Holocene maritime adaptations in the Aleutian Islands. In Peopling of the New World, J. E. Ericson, R. E. Taylor, and R. Berger, eds. Los Altos, CA: Ballena Press, 35-67.

Aigner, J. S., B. Fullem, D. Veltre et al. 1976. Preliminary reports on the remains from Sandy Beach Bay, a 4300-5600 BP Aleut village. Arctic Anthropol. 13:83-90.

Bean, K. W. 1999. The Holocene Eruptive History of Makushin Volcano, Alaska. M.A. thesis, University of Alaska, Fairbanks.

Black, R. F. 1974. Late Quaternary sea level changes, Umnak Island, Aleutians: Their effects on ancient Aleuts and their causes. Quaternary Res. 4:264-281.

Coltrain, J. B., M. G. Hayes, and D. O'Rourke. 2006. Hrdlička's Aleutian population-replacement hypothesis: A radiometric evaluation. Curr. Anthropol. 47:537-548.

Crockford, S., and G. Frederick. 2007. Sea ice expansion in the Bering Sea during the Neoglacial: Evidence from archaeozoology. Holocene 17:699-706.

Dall, W. H. 1877. On succession in the shell-heaps of the Aleutian Islands. In Contributions to North American Ethnology, v. 1, pt. 1, Tribes of the Extreme Northwest, by D. H. Dall. Washington, DC: U.S. Government Printing Office, 41-91.

Davis, B. L. 2001. Sea mammal hunting and the Neoglacial: An archaeofaunal study of environmental change and subsistence technology at Margaret Bay, Unalaska. In Archaeology in the Aleut Zone of Alaska, D. E. Dumond, ed. University of Oregon Anthropological Papers 58. Eugene: Museum of Natural and Cultural History, University of Oregon, 71-85.

Davis, R. S., and R. A. Knecht. 2005. Evidence for the Arctic Small Tool Tradition in the eastern Aleutians. Alaska J. Anthropol. 3:51-65.

Dumond, D. E., ed. 2001a. Archaeology in the Aleut Zone of Alaska. University of Oregon Anthropological Papers 58. Eugene: Museum of Natural and Cultural History, University of Oregon.

Dumond, D. E. 2001b. Toward a (yet) newer view of the (pre)history of the Aleutians. In Archaeology in the Aleut Zone of Alaska, D. E. Dumond, ed. University of Oregon Anthropological Papers 58. Eugene: Museum of Natural and Cultural History, University of Oregon, 298-309.

Dumond, D. E. 2005. The Arctic Small Tool adaptation in southern Alaska. Alaska J. Anthropol. 3:67-78.

Dumond, D. E., and R. L. Bland. 1995. Holocene prehistory of the northernmost North Pacific. $J$. World Prehist. 9:401-451.

Dumond, D. E., and R. A. Knecht. 2001. An early blade site in the eastern Aleutians. In Archaeology in the Aleut Zone of Alaska, D. E. Dumond, ed. University of Oregon Anthropological Papers 58. Eugene: Museum of Natural and Cultural History, University of Oregon, 9-34.

Ellis, C. J. 1997. Factors influencing the use of stone projectile tips: An ethnographic perspective. In Projectile Technology, H. Knecht, ed. New York: Plenum, 37-78.

Gilbert, M. T. P., T. Kivisild, B. Gronnow et al. 2008. Paleo-Eskimo mtDNA genome reveals matrilineal discontinuity in Greenland. Science 320:1787-1789.

Hatfield, V. 2006. Historical Continuity from Shemya to Dutch Harbor: An Evolutionary Analysis of Chipped Stone Technology in the Aleutian Islands. Ph.D. dissertation, University of Kansas, Lawrence.

Hausler-Knecht, P. 1993. Early prehistory of the Kodiak archipelago. Paper presented at the NSF-JSPS seminar "Origins, Development, and Spread of North Pacific-Bering Sea Maritime Cultures," Honolulu, June 2-8, 1993.

Hoffman, B. 1999. Agayadan Village: Household archaeology on Unimak Island, Alaska. J. Field Archaeol. 26:147-161.

Hrdlička, A. 1945. The Aleutian and Commander Islands and Their Inhabitants. Philadelphia: Wistar Institute of Anatomy and Biology.

Jochelson, W. 1925. Archaeological Investigations in the Aleutian Islands. Washington, DC: Carnegie Institution of Washington. 
Knecht, R. A., and R. S. Davis. 2001. A prehistoric sequence for the eastern Aleutians. In Archaeology in the Aleut Zone of Alaska, D. E. Dumond, ed. University of Oregon Anthropological Papers 58. Eugene: Museum of Natural and Cultural History, University of Oregon, 267-288.

Knecht, R. A., and R. S. Davis. 2004. South Channel Bridge Project no. MGS-STP-BR-0310(S)/52930: Amaknak Bridge Site Data Recovery Project Final Report. Anchorage: Alaska Department of Transportation and Public Facilities.

Knecht, R. A., and R. S. Davis. 2008. The Amaknak Bridge Site: Cultural change and the Neoglacial in the eastern Aleutians. Arctic Anthropol. 45:61-78.

Knecht, R. A., R. S. Davis, and G. S. Carver. 2001. The Margaret Bay Site and eastern Aleutian prehistory. In Archaeology in the Aleut Zone of Alaska, D. E. Dumond, ed. University of Oregon Anthropological Papers 58. Eugene: Museum of Natural and Cultural History, University of Oregon, 35-69.

Laughlin, W. S. 1975. Aleuts: Ecosystem, Holocene history, and Siberian origin. Science 189:507-515.

Laughlin, W. S. 1980. Aleuts: Survivors of the Bering Land Bridge. New York: Holt, Rinehart \& Winston.

Liapunova, R. G. 1996. Essays on the Ethnography of the Aleuts. Fairbanks: University of Alaska Press.

Maschner, H. D. G. 1999. Prologue to the prehistory of the lower Alaska Peninsula. Arctic Anthropol. 36:84-102.

Maschner, H. D. G. 2004. Redating the Hot Springs Village site in Port Moller, Alaska. Alaska J. Anthropol. 2:100-116.

Maschner, H. D. G., and J. W. Jordan. 2001. The Russell Creek manifestation of the Arctic Small Tool Tradition of the western Alaska Peninsula. In Archaeology in the Aleut Zone of Alaska, D. E. Dumond, ed. University of Oregon Anthropological Papers 58. Eugene: Museum of Natural and Cultural History, University of Oregon, 151-171.

Mason, O. K. 2001. Catastrophic environmental change and the middle Holocene transition in the Aleutian Islands. In Archaeology in the Aleut Zone of Alaska, D. E. Dumond, ed. University of Oregon Anthropological Papers 58. Eugene: Museum of Natural and Cultural History, University of Oregon, 105-121.

Maxwell, M. S. 1985. Prehistory of the Eastern Arctic. Orlando, FL: Academic Press.

McCartney, A. P. 1984. Prehistory of the Aleutian region. In Handbook of North American Indians, v. 5, Arctic, D. Damas, ed. Washington, DC: Smithsonian Institution, 119-135.

McCartney, A. P., and D. W. Veltre. 1996. Anangula core and blade site. In American Beginnings: The Prehistory and Paleoecology of Beringia, F. H. West, ed. Chicago: University of Chicago Press, 443-450.

Okada, H., A. Okada, K. Yajima et al. 1986. Preliminary report of the 1984 excavations at Port Moller. Qaluyaarmiut 3:1-35.

O'Leary, M. 2001. Volcanic ash stratigraphy for Adak Island, central Aleutian archipelago. In Archaeology in the Aleut Zone of Alaska, D. E. Dumond, ed. University of Oregon Anthropological Papers 58. Eugene: Museum of Natural and Cultural History, University of Oregon, 215-233.

Rasmussen, M., Y. Li, S. Lindgreen et al. 2010. Ancient human genome sequence of an extinct PalaeoEskimo. Nature 463:757-762.

Reimer, P. J., M. G. L. Baillie, E. Bard et al. 2009. IntCal09 and Marine09 radiocarbon age calibration curves, 0-50,000 years cal BP. Radiocarbon 51:1111-1150.

Rogers, J. S., M. R. Yarborough, and C. L. Pendleton. 2009. An Anangula period core-and-blade site on Amaknak Island, eastern Aleutians. Alaska J. Anthropol. 7:153-165.

Stuiver, M., and P. J. Reimer. 1993. Extended ${ }^{14} \mathrm{C}$ database and revised CALIB radiocarbon calibration program. Radiocarbon 35:215-230.

Turner, C. G., II, J. S. Aigner, and L. R. Richards. 1974. Chaluka stratigraphy, Umnak Island, Alaska. Arctic Anthropol. 11:125-142.

Veltre, D. W., and A. P. McCartney. 2001. Ethnohistorical archaeology at the Reese Bay Site, Unalaska Island. In Archaeology in the Aleut Zone of Alaska, D. E. Dumond, ed. University of Oregon 


\section{4 / DAVIS AND KNECHT}

Anthropological Papers 58. Eugene: Museum of Natural and Cultural History, University of Oregon, 87-104.

Veniaminov, I. 1984. Notes on the Islands of the Unalaska District. Kingston, Canada: Limestone Press.

Willey, G., and P. Phillips. 1958. Method and Theory in American Archaeology. Chicago: Chicago University Press.

Yarborough, M. R. 1988. Archaeological Testing of UNL 048, The Margaret Bay Site, Unalaska, Alaska. Unalaska, AK: Ounalashka Corporation.

Yesner, D. R., and R. N. Mack. 1995. Margaret Bay knoll and the origins of Aleut and Pacific Eskimo cultures. Paper presented at Annual Meeting of the Society for American Archaeology, Minneapolis, May 3-7, 1995.

Zlojutro, M., R. Rubicz, E. J. Devor et al. 2006. Genetic structure of the Aleuts and circumpolar populations based on mitochondrial DNA sequences: A synthesis. Am. J. Phys. Anthropol. 129:446-464. 